\title{
Psychometric properties of the Burnout Inventory for Referees (BIR) for Brazilian Basketball Referees
}

\section{Propiedades psicométricas del Burnout Inventory for Referees (BIR) para Árbitros Brasileiros de Baloncesto}

\section{Propriedades psicométricas do Burnout Inventory for Referees (BIR) para Árbitros Brasileiros de Basquetebol}

\author{
De Almeida, F.R. ${ }^{1}$, Pires, D.A. ${ }^{2}$, Weinberg, R.S ${ }^{3}$, Brandão, M.R.F. ${ }^{1}$ \\ ${ }^{1}$ USJT, Universidade São Judas Tadeu, São Paulo, Brazil; ${ }^{2}$ UFP, Universidade Federal do Pará, Pará, \\ Brazil; ${ }^{3}$ Miami University, Oxford, Ohio;
}

\begin{abstract}
The main goal of this paper was to verify the psychometric properties of the Burnout Inventory for Referees (BIR) on Brazilian basketball referees. A total of 395 basketball referees were evaluated (age: $35.11 \pm 9.18$ years), of both gender $($ male $=319$ and female $=76$ ), with an average experience time of $12.34 \pm 7.83$ years, who answered demographic identification questionnaires, BIR and BRUMS. Factor validity was estimated using Confirmatory Factor Analysis (AFC) with the Maximum Likelihood estimation method. As homoscedasticity was rejected, the comparison between groups was performed using ANOVA with Welch's correction followed by the Games-Howell post-test. The correlation between the scores of the BIR-AB factors and the variables age and length of experience was assessed using Pearson's Correlation Analysis (r). The level of significance adopted was 5\%. After the performance of the AFC and insertion of the second-order hierarchical model (MHSO), a new model was proposed, called BIR-AB (Burnout Inventory for Referees for Brazilian basketball referees), containing two negative dimensions (EFE and DES) and a positive (RE), with adequate adjustment indexes, acceptable and invariant reliability between the gender and in the test/validation sample and the divergent validity was attested.
\end{abstract}

Keywords: referees; basketball; burnout; psychometry.

\section{RESUMEN}

El objetivo principal de este estudio fue verificar las propiedades psicométricas del Burnout Inventory for Referees (BIR) para los árbitros brasileños de baloncesto. Se evaluaron 395 árbitros de baloncesto (edad: 35,11 \pm 9,18 años), de ambos sexos (hombre $=319$ y mujer $=76$ ), con tiempo de experiencia de 12,34 \pm 7,83 años, que respondieron los cuestionarios de identificación demográfica, BIR e BRUMS. La validez factorial se estimó utilizando el Análisis Factorial Confirmatorio (AFC) con el método de estimación de Máxima Verosimilitud. Como se rechazó la 


\section{De Almeida et al.}

homocedasticidad, la comparación entre los grupos se realizó utilizando ANOVA com la correción de Welch seguida de la prueba posterior Games-Howell. La correlación entre las puntuaciones de los factores BIR-AB y las variables edad y duración de la experiência se evaluó mediante el Análisis de Correlación de Pearson (r). El nível de significación adoptado fue del 5\%. Después de la realización de la AFC y la inserción del modelo jerárquico de segundo orden (MHSO), se propuso um nuevo modelo, llamado BIR-AB (Burnout Inventory for Referees para los árbitros de baloncesto brasileños), que contiene dos dimensiones negativas (EFE e DES) e una positiva (RE), con índices de ajuste adecuados, confiabilidad aceptable e invariante entre los sexos y en la muestra de puebra/validación y se confirmó la validez divergente.

Palabras clave: árbitros; baloncesto; burnout; psicometría.

\section{RESUMO}

O objetivo principal desse estudo foi verificar as propriedades psicométricas do Burnout Inventory for Referees (BIR) para árbitros brasileiros de basquetebol. Foram avaliados 395 árbitros de basquetebol (idade: $35,11 \pm 9,18$ anos), de ambos os sexos (masculino=319 e feminino=76), com tempo médio de experiência de 12,34 \pm 7,83 anos, que responderam aos questionários de identificação demográfica, BIR e BRUMS. A validade fatorial foi estimada utilizando-se a Análise Fatorial Confirmatória (AFC) com método de estimação da Máxima Verossimilhança. Como a homocedasticidade foi rejeitada, a comparação entre os grupos foi realizada por meio da ANOVA com correção de Welch seguido pelo pós-teste de Games-Howell. A correlação entre os escores dos fatores do BIR-AB e as variáveis idade e tempo de atuação foi avaliada a partir da Análise de Correlação de Pearson (r). O nível de significância adotado foi $5 \%$. Após a realização da AFC e inserção do modelo hierárquico de segunda ordem (MHSO), um novo modelo foi proposto, chamado de BIR-AB (Burnout Inventory for Referees para árbitros brasileiros de basquetebol), contendo duas dimensões negativas (EFE e DES) e uma positiva (RE), com índices adequados de ajustamento, confiabilidade aceitável e invariante entre os sexos e na amostra teste/validação e a validade divergente foi atestada.

Palavras-chave: árbitros; basquetebol; burnout; psicometria.

\section{INTRODUCTION}

The burnout syndrome manifests itself in the individual when he/she has low expectations regarding professional activities, related to fatigue and lack of enthusiasm due to the constant interaction with work demands. This emotional status generates feelings of unhappiness with oneself and dissatisfaction with professional involvement, which can turn into pessimistic, negative, and even aggressive attitudes towards service recipients (Guedes \& Souza, 2016). The maintenance of characteristics like these results, over time, in the diagnosis of burnout (Maslach \& Jackson, 1981).

The concept of the syndrome, initially identified in health professionals, has been systematically expanded to different occupational groups, including the sports field. In this context, the first researches were carried out with coaches (Caccese \& Mayerberg,
1984; Dale \& Weinberg, 1989), athletes (Raedeke, 1997; Raedeke \& Smith, 2001; Raedeke \& Smith, 2009) and with an even more peculiar population in sports environment: the referees, when Weinberg and Richardson (1990) developed the BIR (burnout inventory for referees), an inventory composed of 16 items for assessing the burnout syndrome specifically on these professionals. However, this instrument was not validated by the authors: the process of evaluating psychometric properties, reliability, and validity of the instrument was performed only by Brandão, Serpa, Rosado and Weinberg (2014), for Brazilian and Portuguese soccer referees.

One of the main barriers to a better understanding of burnout is represented by the lack of instruments for measuring the syndrome in sports. The questionnaires generally used by sports researchers are derived from studies that addressed burnout in other professions, especially doctors, nurses, and teachers. Examples of 


\section{Burnout Inventory for Referees (BIR) in Brazilian Basketball Referees}

this are the studies about burnout in basketball referees (Al-Haramlah, 2018; Karademir, 2012; Koh \& Hanrahan, 2017; Pedrosa \& García-Cueto, 2016), in which two different instruments were used (Athlete Burnout Questionnaire "ABQ", specific for athletes, and Maslach Burnout Inventory "MBI", used for the general population), which shows us a lack of adequate studies to evaluate the burnout syndrome in basketball referees. Considering this, and to obtain information about the manifestation of burnout in referees, this study aimed to verify the psychometric properties of the Burnout Inventory for Referees (BIR) for Brazilian basketball referees.

Table 1. Sample characterization [n (\%)] according to gender, category, region, and academic background.

\begin{tabular}{llc}
\hline \multicolumn{1}{c}{ GRUP } & CATEGORY & FREQUENCY (\%) \\
\hline \multirow{2}{*}{ GENDER } & Male & $319(80,8)$ \\
& Female & $76(19,2)$ \\
\hline \multirow{2}{*}{ CATEGORY } & Regional & $257(65,1)$ \\
& National & $109(27,6)$ \\
& International & $29(7,3)$ \\
\hline \multirow{2}{*}{ REGION } & Midwest & $52(3,2)$ \\
& Northeast & $81(20,5)$ \\
& North & $18(4,6)$ \\
& South & $100(25,2)$ \\
& Southeast & $144(36,4)$ \\
& High school & $40(10,1)$ \\
& Undergraduation & $252(63,8)$ \\
& Graduation & $103(26,1)$
\end{tabular}

Note: A category is understood as the competitive level of the athletes in which the referees act.

\section{METHODOLOGY}

\section{Participants}

The study addressed 395 basketball referees belonging to the Brazilian Basketball Confederation (CBB) with an average age of $35.11 \pm 9.18$ years and with an average performance time of $12.34 \pm 7.83$ years. The distribution of individuals according to their characteristics is given in Table 1 .

\section{Instruments}

To collect data on the sample's characterization variables, a questionnaire designed specifically for this purpose was used, containing nine questions: research date, state (federation), gender, date of birth, category, specific function on the court, academic background, length of experience, and date of the last game played (exclusion criteria).

The instrument used to collect information regarding the burnout syndrome in Brazilian basketball referees was the Burnout Inventory for Referees - BIR (Weinberg \& Richardson, 1990), however, there were no validation studies carried out by the authors.

The BIR translation followed the guidelines for crosscultural adaptations of measuring instruments in the health sciences (Beaton, Bombardier, Guillemin \& Ferraz, 2002) and consisted of seven steps that included: (1) translation of the BIR from English to Portuguese by two professionals from both respective countries, sports psychologists and fluent in the English language, generating two versions (T1 and 


\section{De Almeida et al.}

T2) of the instrument; (2) synthesis of the two translations to determine the thirds version (T3) of the instrument; (3) reverse translation of T3 by two English native speakers and fluent in the Portuguese language, resulting in versions $\mathrm{T} 4$ and $\mathrm{T} 5$; (4) synthesis of the last two translations (T4 and T5) to determine the T6 version of the instrument; (5) evaluation of the inventory by specialists (Ph.D. professionals), creating the $\mathrm{T} 7$ version of the instrument; (6) comparison of the T7 version with the version translated by Brandão et al. (2014); (7) BIR final version in Portuguese.

The original BIR (Weinberg \& Richardson, 1990) assesses both, frequency and intensity of the burnout symptoms. Nevertheless, in this study, the final version was used only with the frequency scale, since burnout is a cumulative process of symptoms over time. Thus, the frequency with which symptoms appear is more relevant than their intensity. For this, the referees read carefully each statement and decided if they have ever felt that way "in the past 12 months", and choose a number that best describes the frequency of each of the responses on a Likert scale that varied from "not frequent" (score 1) to "very frequent" (score 7).

It is worth mentioning that the application of the BIR presents minimal risk to the biopsychosocial integrity of the basketball referees since the data obtained from the responses provided to the BIR are confidential, of restricted use by the researchers, and were used exclusively for this scientific research.

\section{Research procedures}

The permission for the application of Brunel Mood Scale for Brazilian Referees "BRUMS-AB" (Almeida, Silva, Campos, Vendramini \& Brandão, 2017), was approved by the CBB. Then, the referees were contacted by email contain an explanatory video about the study's main goals and guidelines for their voluntary participation. The contents of their responses were treated confidentially. Due to the geographic extent of Brazil, data collection was carried out by e-mail, the most appropriate method to reach participants in the 27 Brazilian states. The use of internet resources, through e-mail, points to an increase in the participants' response rate (Lonsdale, Hodge \& Rose, 2006).

All participants agreed on their voluntary participation in the study by signing a specific document. Posteriorly, the referees and the table officials received an email containing the Google ${ }^{\mathrm{TM}}$ Docs link with the Portuguese version of the BIR inventory and the sample characterization form. Both instruments were answered according to the participants' availability. Responses, in addition to being anonymous, were forwarded directly to the researcher coordinator, without contact to any arbitration supervisors, thus ensuring the confidentiality of the arbitrators and table officials' responses. The research was approved by the Ethics and Research Committee of São Judas Tadeu University $\left(\mathrm{n}^{\circ} 1,509,169\right)$, based on the rules of Resolution 466/2012.

\section{Data Analysis Procedures}

The psychometric sensitivity of the BIR items was assessed based on measures of central tendency, variability, and distribution form of the responses given. Asymmetry absolute value less than three and kurtosis less than seven indicates that the responses given have a normal distribution, attesting to the psychometric sensitivity of the item (Kline, 2015; Marôco, 2014). Multivariate normality was assessed using the Mardia's Test, considering normality when its absolute value is less than 3 (Marôco, 2014).

The construct validity and factorial model of the original scale (M1) was verified by classifying the 16 items according to the theoretical matrix of burnout in sport (Raedeke \& Smith, 2001), being divided into physical and emotional exhaustion (EFE - items 1, 2, $7,10,11$ and 14), reduced sense of sports achievement (RSRE - items 4, 5, 6, 9, 12 and 15), and depersonalization (DES - items 3, 8, 13 and 16).

After that, it was testes the factorial model (M2) proposed by Brandão et al. (2014). It is composed of nine items, divided into physical and emotional exhaustion (EFE - items 1, 2, and 14), reduced sense of sports achievement (RSRE - items 9, 11, and 15) and depersonalization (DES - items 6, 8, and 13). 


\section{Burnout Inventory for Referees (BIR) in Brazilian Basketball Referees}

We proposed a third model (M3) based on the research carried out by Marôco, Tecedeiro, Martins, and Meireles (2008); Pereira (2015); Ruviaro and Bardagi (2010); Tamayo and Tróccoli (2009). The M3 has the following configuration: physical and emotional exhaustion (EFE - items 1, 2, 10, 11, and 14), depersonalization (DES - items 3, 4, 6, 8, 9, 13, 15, and 16), and sports performance (RE - items 5, 7, and 12). Construct validity was tested in all models based on factorial, convergent, and discriminant validity.

Factorial validity was estimated using Confirmatory Factor Analysis (CFA) with the maximum likelihood estimation method. The indices used to assess the quality of adjustment were the chi-square ratio for degrees of freedom $(\chi 2 / \mathrm{gl})$, Comparative Fit Index (CFI), Goodness of Fit Index (GFI), Adjusted Goodness of Fit Index (AGFI), Normed Fit Index (NFI) and Root Mean Square Error of Approximation (RMSEA). Finally, the factor weights of the items $(\lambda)$ were also considered.

The model adjustment was considered adequate when $\lambda \geq 0,40, \chi^{2} / \mathrm{g} 1 \leq 5,0, \mathrm{CFI}$, GFI, AGFI, NFI $\geq 0,90$, and RMSEA $\leq 0,10$ (Marôco, 2014). To verify the existence of a correlation between the items errors, the modification indexes estimated using the Lagrange Multiplier (LM) method were considered. LM values greater than eleven were verified (Hair, Anderson, Tatham \& Black, 2009; Marôco, 2014).

The convergent validity was estimated from the Average Extracted Variance (AVE), following the proposal of Fornell and Larcker (1981), being considered adequate with values above 0.50. The discriminant validity was estimated from the correlational analysis, being adequate when $\mathrm{AVE}_{\mathrm{i}}$ and $\mathrm{AVE}_{\mathrm{j}}$ are higher than $\mathrm{r}_{\mathrm{ij}}$ (Fornell and Larcker, 1981; Kline, 2015; Marôco, 2014).

The invariance analysis of the factorial model in independent samples was estimated from the multigroup analysis using the difference of CFI $(\triangle \mathrm{CFI})$ for the factor weights $(\lambda)$, intercepts (i), and covariance and residuals (Cov/Res). Invariance was assumed when the CFI reduction was greater than -0.01 .
Initially, the sample was subdivided into two parts, randomly, by the statistical analysis program itself, called "Sample-Test" $(\mathrm{n}=188)$ and "SampleValidation" $(n=207)$. When the factorial weights of the models did not differ significantly, weak invariance (metric invariance) was considered. If the factor weights and the intercepts do not differ between groups, it would be considered a strong invariance (scalar invariance). On the other hand, if there was no difference in factor weights, intercept, covariance, and residuals, the existence of strict invariance would be considered (Marôco, 2014). The sample was also subdivided according to gender (male and female) to verify whether the BIR would be invariant for these subsamples. The invariance was estimated as previously described.

To assess reliability, the Standardized Cronbach's alpha coefficient $(\alpha)$ and the Composite Reliability (CC) were estimated, where values above 0.6 being considered acceptable (Hair et al., 2009). The BIR divergent validity was assessed using Pearson's Correlational Analysis (r) between the BIR dimensions and the BRUMS-AB dimensions (Almeida et al., 2017), with a significance level of 5\%.

The analyzes were conducted using the SPSS program (V. 22, SPSS An IBM Company, Chicago, IL) and AMOS (V. 22, SPSS An IBM Company, Chicago, IL). The general score for each dimension was calculated from the regression weight matrix obtained by the AFC. The weight attributed to each item was multiplied by the participant's response and the estimated value of each item was summed, obtaining a general weighted score for each dimension, through a mathematical expression, called algorithm.

\section{RESULTS}

Regarding psychometric sensitivity, the summary measures of the responses given to the BIR items are shown in Table 2. It is observed that no item violated the assumption of normality. The data showed multivariate normality (Mardia's Test $=2.42$ ). 


\section{De Almeida et al.}

Table 2. Descriptive statistics of the responses given by the participants to the items of the Burnout Inventory for Referees (BIR).

\begin{tabular}{|c|c|c|c|c|c|c|c|}
\hline ITEM & MEAN & MEDIAN & $\begin{array}{c}\text { STANDAR } \\
\text { DESVIATION }\end{array}$ & MINIMUM & MAXIMUM & ASYMMETRY & CURTOSIS \\
\hline SBF1 & 2,40 & 2 & 1,28 & 1 & 7 & 0,958 & 0,779 \\
\hline SBF2 & 1,82 & 1 & 1,32 & 1 & 7 & 1,839 & 2,81 \\
\hline SBF3 & 1,92 & 1 & 1,48 & 1 & 7 & 1,79 & 2,551 \\
\hline SBF4 & 3,03 & 2 & 2,05 & 1 & 7 & 0,689 & $-0,841$ \\
\hline SBF5 & 3,97 & 4 & 2,19 & 1 & 7 & $-0,011$ & $-1,382$ \\
\hline SBF6 & 1,69 & 1 & 1,16 & 1 & 7 & 2,13 & 4,758 \\
\hline SBF7 & 4,20 & 4 & 1,94 & 1 & 7 & $-0,216$ & $-1,05$ \\
\hline SBF8 & 2,16 & 1 & 1,70 & 1 & 7 & 1,458 & 1,082 \\
\hline SBF9 & 2,87 & 2 & 2,01 & 1 & 7 & 0,746 & $-0,75$ \\
\hline SBF10 & 3,89 & 4 & 1,86 & 1 & 7 & 0,157 & $-1,025$ \\
\hline SBF11 & 1,80 & 1 & 1,31 & 1 & 7 & 1,994 & 3,829 \\
\hline SBF12 & 4,05 & 4 & 2,18 & 1 & 7 & $-0,106$ & $-1,404$ \\
\hline SBF13 & 2,53 & 1 & 1,94 & 1 & 7 & 0,969 & $-0,389$ \\
\hline SBF14 & 2,73 & 2 & 1,82 & 1 & 7 & 0,926 & $-0,201$ \\
\hline SBF15 & 1,91 & 1 & 1,46 & 1 & 7 & 1,788 & 2,551 \\
\hline SBF16 & 2,58 & 2 & 1,76 & 1 & 7 & 1,017 & 0,045 \\
\hline
\end{tabular}

Initially, the complete theoretical model (M1) was tested according to the theoretical matrix of burnout in sport (Raedeke and Smith, 2001), whose adjustment of the model before after the second refinement (M1b) is shown in Figure 1. This was the best adjustment obtained for this theoretical proposal, although adequate values of CFI and RMSEA are not observed.

After attempts at adjustment, the factor weights remained below 0.4 and the convergent, discriminant, and reliability validities were compromised in the dimensions. It is worth mentioning that by inspecting the modification indices, no correlations were found between the item's errors. There was an attempt to test a Second-Order Hierarchical Model - MHSO (M1b), however, it was not possible, due to the existence of negative variance in the disorders.
The adjustment of the theoretical model proposed (M2) by Brandão et al. (2014) and the last model after adjustment are shown in Figure 2. It was observed that all factor weights had values above 0.4. Nevertheless, CFI and RMSEA did not present adequate values. Thus, the modification indices were checked and there was a high correlation between the errors in items 9 and $14(\mathrm{LM}=76.153)$. Additionally, the correlation between these items does not make sense from a theoretical point of view, since they are allocated to different factors. The M2e model presented adequate values for CFI, GFI, and RMSEA, however, the convergent, discriminant, and reliability validities were compromised in these models. 


\section{Burnout Inventory for Referees (BIR) in Brazilian Basketball Referees}

M1 - Factorial model acoording to the theorical matrix of burnout in sport. (Raedeke e Smith, 2001).

$\chi^{2}$ /gl=10,345; CFI=,531; GFI=,671; AGFI=,557; NFI=,510; RMSEA=,154 $r^{2}=0,16-0,92 ; A V E=0,20-0,54 ; \alpha=0,4-0,6 ; C C=0,5-0,6$

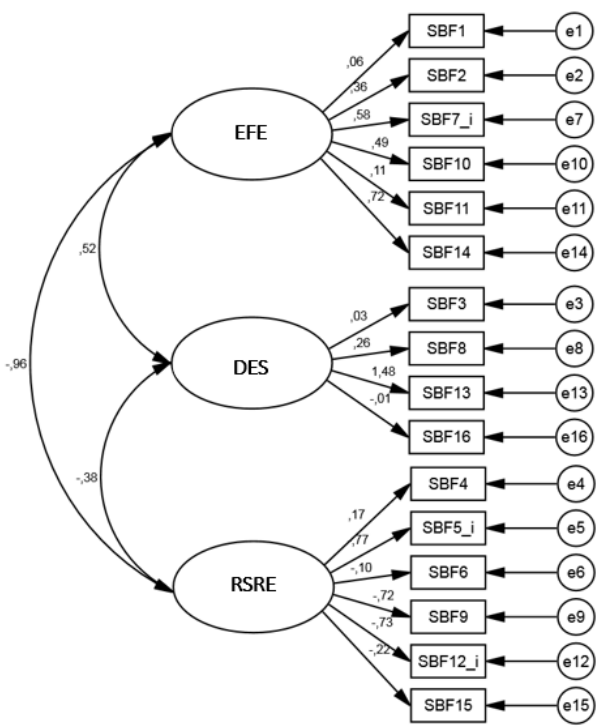

M1b - Factorial model acoording to the theorical matrix of burnout in sport. (Raedeke e Smith, 2001).

$\chi^{2} / \mathrm{gl}=6,732 ; \mathrm{CFI}=, 855 ; \mathrm{GFI}=, 901 ;$ AGFI=,814; NFI=,836; RMSEA=,121 $r^{2}=0,00-1,00 ; A V E=0,12-0,56 ; \alpha=0,2-0,7 ; C C=0,2-0,8$

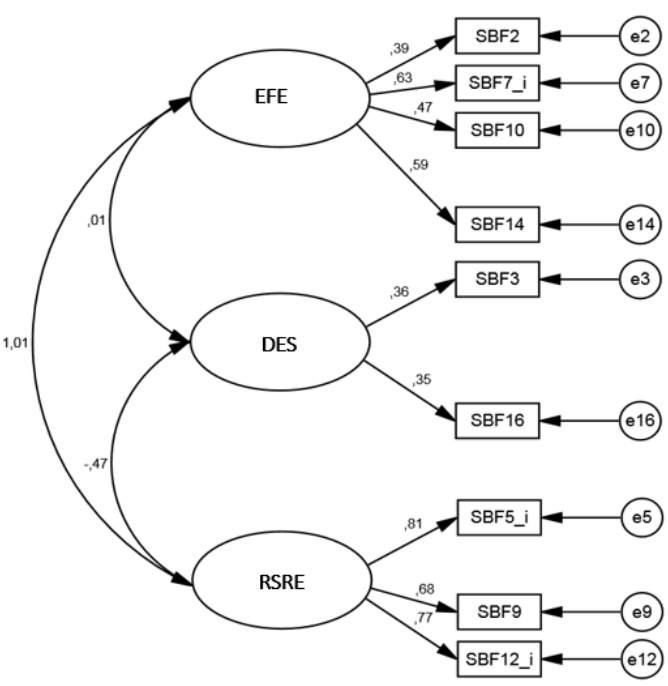

Figure 1. Adjustment of the complete (M1) and refined (M1b) theoretical model according to the theoretical matrix of burnout in sports (Raedeke \& Smith, 2001).
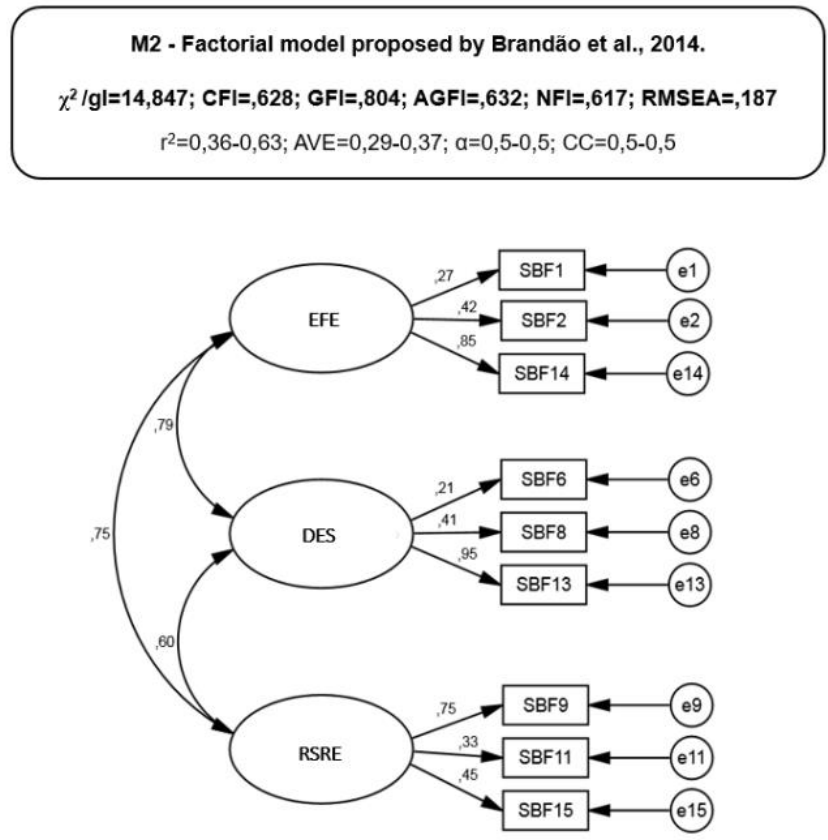

M2e - Factorial model proposed by Brandão et al., 2014. $\chi^{2} / \mathrm{gl}=2,831 ; \mathrm{CFI}=, 969 ; \mathrm{GFI}=, 986 ; \mathrm{AGFI}=, 952 ; \mathrm{NFI}=, 954 ; \mathrm{RMSEA}=, 068$ $r^{2}=0,32-0,77 ; A V E=0,23-0,46 ; a=0,3-0,6 ; C C=0,3-0,6$

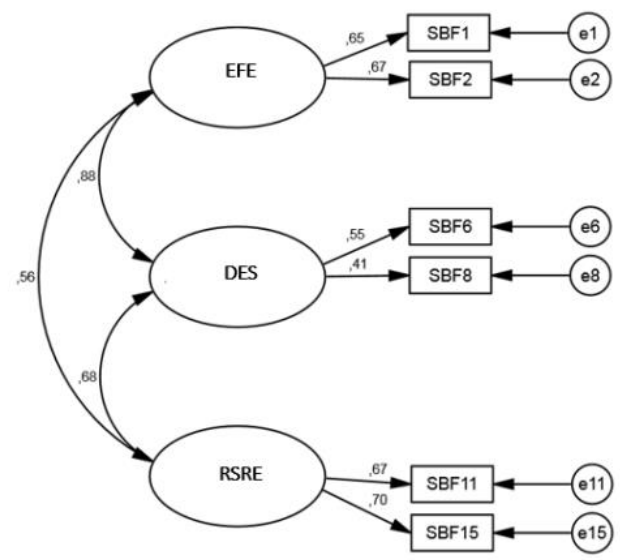

Figure 2. Adjustment of the complete (M2) and refined (M2e) theoretical model according to the theoretical matrix of burnout in sports (Brandão et al., 2014). 


\section{De Almeida et al.}

The adjustment of the theoretical model proposed in the present study (M3) is shown in Figure 3. It was noticed that the adjustment, as well as many factor weights, were not adequate (items 1, 3, 4, 6, 8, 11, and 13). Before beginning the refinement, excluding items with low factor weight, it was decided to initially exclude item 13, since it presented a problem in the previously tested theoretical models.

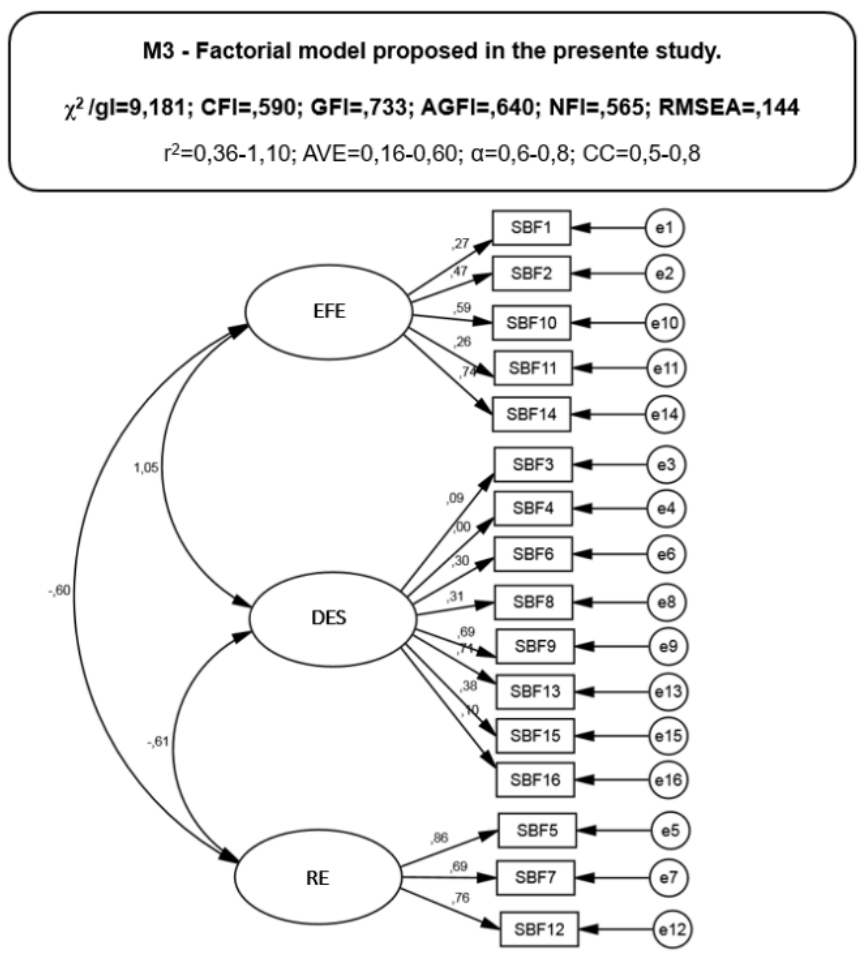

Figure 3. Adjustment of the complete theoretical model (M3).

After that, based on the explained theory of M3, a model was tested with the maintenance of the following items: EFE (items 2, 10, 14), DES (items 9, 13, and 15), and RE (items 5, 7, and 12). The configuration of this model was based on analyzes carried out in a previous stage. Despite presenting good levels of adjustment quality, item 15 presented low weighting factor, starting with the refinement of this model after the exclusion of this item. The refined model showed good levels of adjustment quality, despite having a correlation above 1.00, with impairment of convergent validity in the EFE and DES dimensions, and impairment of the discriminating validity between the EFE - DES and EFE - RE dimensions. Reliability showed acceptable values according to Hair et al. (2009).

Due to the existence of a high correlation between the first-order dimensions, it was highly relevant to introduce a second-order factor (Marôco et al., 2008), and the adjustment of the Second Order Hierarchical Model (MHSO), called total burnout (BT). For proper adjustment, it was necessary to fix the variance of the disturbances of the EFE and DES dimensions (M3f Figure 4).

As observed in the first-order model, convergent validity and discriminant validity were compromised in some factors, and reliability remained with acceptable values.

After the validation process, the factorial model (M3f) will be referred to as Burnout Inventory for Referees for Brazilian Basketball Referees (BIR-AB), and its new structure is shown in Table 3, containing three dimensions, with their respective items, which assess the frequency of feelings related to burnout. In the first column of this table are shown the items that remained after the adjustment, based on M3f (ID - M3f). The middle column has the item number (reordered by drawing lots) after adjusting the instrument for eight items (ID - BIR-AB). Lastly, in the last column describes the item referring to BIR-AB. 


\section{Burnout Inventory for Referees (BIR) in Brazilian Basketball Referees}
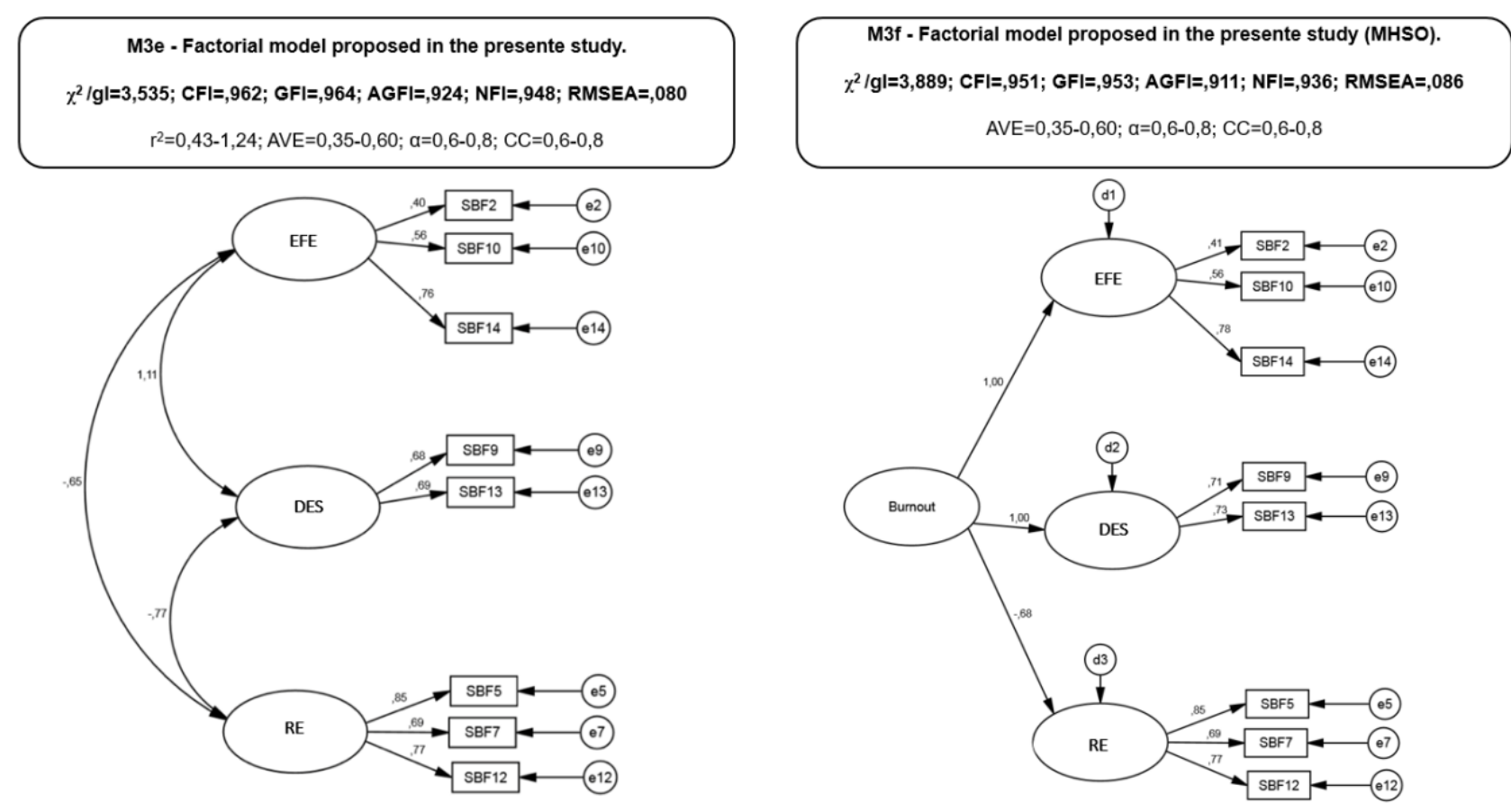

Figure 4. Adjustment of the complete theoretical model (M3e) and the second-order hierarchical model (MHSO) (M3f) proposed in the present study.

Table 3. BIR-AB structure, indicating the three dimensions with their respective items.

\begin{tabular}{lll}
\hline ID - M3f & ID BIR-AB & \multicolumn{1}{c}{ ITEM DESCRIPTION } \\
\hline & Dimension - Physical and Emotional Exhaustion (EFE) \\
ITEM 2 & ITEM 1 & $\begin{array}{l}\text { I feel tired when I get up in the morning and have to face a task } \\
\text { related to arbitration. }\end{array}$ \\
ITEM 10 & ITEM 5 & Working with unruly coaches and players causes me stress. \\
ITEM 14 & ITEM 8 & I am completely exhausted after refereeing a game. \\
\hline & Dimension - Depersonalization (DES) \\
ITEM 9 & ITEM 4 & I am frustrated with the arbitration. \\
ITEM 13 & ITEM 7 & I became more insensitive to people after starting arbitration. \\
\hline & Dimension - Sports Achievement (RE) \\
ITEM 5 & ITEM 2 & I feel fulfilled in arbitration. \\
ITEM 7 & ITEM 3 & I feel energetic. \\
ITEM 12 & ITEM 6 & I feel that through arbitration I am positively influencing others. \\
\hline
\end{tabular}

Table 4 shows the multigroup analysis performed to assess the invariance of the factor models in independent samples (test and validation), and according to gender. For this stage, the models M3e and M3f (first-order model and second-order hierarchical model, respectively) were considered. It should be noted that there was an adequate adjustment for the subsample's "test" and "validation" only for 


\section{De Almeida et al.}

the M3e model $\left(\chi^{2} / \mathrm{gl} \leq 2,84, \quad \mathrm{CFI} \geq 0,93\right.$, and RMSEA $<0,099)$. On the other hand, considering the gender variable, none of the models showed adequate adjustments in the two subsamples. Considering the "test" and "validation" samples, and the "male" and "female" samples, there was a strong invariance of the models.

Table 4. Multigroup analysis to evaluate the factorial models of the Burnout Inventory for Referees (BIR).

\begin{tabular}{|c|c|c|c|c|c|c|c|}
\hline \multirow[b]{2}{*}{ SAMPLE } & \multicolumn{3}{|c|}{ \#AFC SIMULTANEOUS } & \multicolumn{4}{|c|}{${ }^{\dagger} \Delta \mathbf{C F I}$} \\
\hline & $\chi^{2} / \mathbf{g l}$ & FI & RMSEA & $\lambda$ & $\mathbf{i}$ & Cov & Res \\
\hline \multicolumn{8}{|l|}{ M3e } \\
\hline TEST vs VALIDATION & 0,64 & 0,97 & 0,04 & 0,002 & 0,005 & 0,001 & 0,002 \\
\hline MALE vs FEMALE & 0,44 & 0,92 & 0,06 & $-0,008$ & 0,001 & 0,002 & $-0,017$ \\
\hline \multicolumn{8}{|l|}{ M3f } \\
\hline TEST vs VALIDATION & 0,80 & 0,96 & 0,04 & $-0,003$ & 0,005 & 0,003 & 0,002 \\
\hline MALE vS FEMALE & 0,58 & 0,91 & 0,06 & $-0,006$ & 0,001 & 0,000 & $-0,015$ \\
\hline
\end{tabular}

Note. \#AFC: confirmatory factor analysis, $\chi^{2} / \mathrm{gl}$ : ratio between chi-square and degrees of freedom, CFI: comparative fit index; RMSEA: root mean square error of approximation; $\uparrow \Delta \mathrm{CFI}$ : difference in CFI; Cov (Covariance); Res (Waste).

Table 5. Correlation (r, (p)) between the dimensions of the BIR-AB and the dimensions of the BRUMS-AB Humor Scale.

\begin{tabular}{lcccc}
\hline & \multicolumn{4}{c}{ BRUMS-AB } \\
\cline { 2 - 4 } \multicolumn{1}{c}{ BIR-AB } & FATIGUE & FORCE & $\begin{array}{c}\text { IMBALANCE } \\
\text { EMOTIONAL }\end{array}$ & WORRY \\
\hline EFE & $0,046(0,42)$ & $-0,052(0,36)$ & $0,062(0,28)$ & $0,003(0,96)$ \\
DES & $0,033(0,57)$ & $-0,079(0,17)$ & $0,054(0,34)$ & $0,007(0,90)$ \\
RE & $0,032(0,58)$ & $0,114(0,05)$ & $-0,084(0,14)$ & $-0,029(0,61)$ \\
BT & $0,038(0,51)$ & $-0,066(0,25)$ & $0,062(0,28)$ & $0,005(0,93)$ \\
\hline
\end{tabular}

Note. EFE (physical and emotional exhaustion); DES (depersonalization); RE (sports performance); BT (total burnout).

Table 5 shows the correlation between the global score for the dimensions of the BIR-AB and the scores for the dimensions of the BRUMS-AB. As the correlation between the dimensions of the BIR-AB and BRUMS$A B$ instruments was non-existent, there is an adequate divergent validity of the BIR-AB, since BRUMS-AB evaluates a different concept.
Using the weights of the weighted scores calculated by AMOS, it was possible to numerically estimate the total burnout (BT) and the scores of the three dimensions (EFE, DES, RE), through the algorithms generated from the correlation weight matrix, with the expression represented in Figure 4: 


\title{
Burnout Inventory for Referees (BIR) in Brazilian Basketball Referees
}

\author{
$\mathbf{B T}=1,29+0,09$ it $1-0,07$ it $2-0,03$ it $3+0,18$ it $4+0,11$ it $5-0,07$ it $6+0,20$ it $7+0,26$ it 8 \\ $\mathbf{E F E}=0,68+0,08$ it $1-0,04$ it $2-0,02$ it $3+0,26$ it $4+0,09$ it $5-0,02$ it $6+0,27$ it $7+0,21$ it 8 \\ DES $=1,78+0,13$ it $1-0,11$ it $2-0,05$ it $3+0,06$ it $4+0,16$ it $5-0,07$ it $6+0,07$ it $7+0,36$ it 8 \\ $\mathbf{R E}=1,50-0,01$ it $1+0,39$ it $2+0,19$ it $3-0,06$ it $4-0,01$ it $5+0,24$ it $6-0,07$ it $7-0,03$ it 8
}

Figure 4. Algorithm for measuring the scores of each dimension (EFE, DES, RE) and total burnout (BT).

\section{DISCUSSION AND CONCLUSION}

The present study aimed to analyze the psychometric properties of the BIR instrument for Brazilian basketball referees. For this purpose, there were performed the construct validity, internal reliability, invariance of the structural models between gender, and divergent validation with BRUMS-AB (Almeida et al., 2017).

The process was based on models that already exist in the sports literature validated for athletes (Arce, De Francisco, Andrade, Arce, \& Raedeke, 2010; De Francisco, Arce, Andrade, Arce, \& Raedeke, 2009; Fernández et al., 2012; Isoard-Gautheur, Oger, Guillet, \& Martin-Krumm, 2010; Palacios, 2015; Pires, Brandão \& Silva, 2006; Raedeke \& Smith, 2001) and soccer referees (Brandão et al., 2014), whose burnout theorist model shows that they were composed of three dimensions, all of which are negative: physical and emotional exhaustion, reduced sense of sports performance, and depersonalization. After the analysis, these models did not show adequate adjustment indexes, indicating that there was no agreement between the data collected from the basketball referees with the existing theoretical models.

This meant that there was a need to search the literature for other theoretical models that represented the burnout syndrome, even if they did not belong to the sports context. After surveying papers that demonstrated different structures, other models were tested, until the model proposed here has adequate adjustment and theoretical consistency of the construct similar to the model proposed by Marôco et al. (2008), composed of two negatives and one positive burnout dimensions.
Thus, after the BIR validation process, which came to be called $\mathrm{BIR}-\mathrm{AB}$, it maintained the three-factor structure, presenting two negative dimensions (physical and emotional exhaustion and depersonalization) and a positive one (sports performance). There was also a reduction from sixteen to eight items, constituting an adjusted instrument for measuring burnout syndrome in circumstances similar to those investigated in this study with referees, reducing the time of application in the sports context. Different authors (Balluerka \& Gorostiaga, 2012; Marsh, Martin, \& Jackson, 2010; Palacios, 2015) indicate the importance of reduced assessment instruments in the sports environment, since the shorter the time of administration, the greater the possibility of sportsmen maintain high levels of concentration when participating in this type of investigation.

The configuration of the dimensions was described as follows: physical and emotional exhaustion (resulting from the intense demands of arbitration), depersonalization (pattern of insensitive attitudes and behaviors and reduction of affection towards others, combined with a feeling of frustration and tiredness), and sports performance (feelings of competence and pleasure associated with performance in refereeing).

Physical and emotional exhaustion (EFE) is associated with the intense demands of the sport (Raedeke \& Smith, 2001) that interfere in the physical, emotional, and social well-being of the referees. Therefore, reactions such as anxiety, tension, and stress, in addition to physical and psychological tiredness, represent this dimension of burnout. The statements that made it up (I feel tired when I get up in the morning and having to face a task related to refereeing; working with unruly coaches and players cause me stress; and I am completely exhausted after refereeing 


\section{De Almeida et al.}

a game) indicate that aggressive behaviors of coaches and athletes, pressure situations experienced in the game, and the pressure concerning the playing time can trigger adjustment difficulties, emotional isolation, irritability, and concentration difficulties. Both cases can lead to the abandonment of arbitration (Benevides-Pereira, 2001). Thus, the greater the magnitude of your score, the higher the perception of physical and emotional exhaustion.

This dimension has been described in the literature as the first symptom to manifest itself in the burnout process (Lundkvist et al., 2018). Likewise, Garcés de los Fayos (1999) found that among the subscales of burnout, physical and emotional exhaustion is considered the most consistent dimension and that best characterize the syndrome.

Depersonalization (DES) is defined as a perception of decreasing performance in work tasks, as well as manifestations of lack of interest, lack of desire, and lack of concern regarding the act of arbitrating. Additionally, there is a lack of interest in other people involved in this context, generating anxiety, increased irritability, demotivation, reduced goals, and commitment to the results related to arbitration (Lundkvist et al., 2018; Raedeke, 1997). Depersonalization can also be associated with a coping strategy used when mental exhaustion reflects a distance from people directly influenced by the activity (Lee \& Ashforth, 1990; Lundkvist et al., 2018). The statements that made up this dimension (I feel frustrated with arbitration and I became more insensitive to people after starting in arbitration) indicate that the referee may decide to remain aloof or indifferent towards the people for whom he exercises their profession, in an attempt not to intensify the consequences of the syndrome. As in the previous dimension, the greater the magnitude of your score, the higher the perception of depersonalization.

In opposite to the two previous dimensions, sports performance (RE) means that the referee is satisfied with his duties and interpersonal relationships and, consequently, can be understood as a protective factor against burnout. Similarly, it can act as a mechanism of control that seeks to restore psychological losses, resulting in personal fulfillment with the professional activity of the referee. The statements that made up this dimension (I feel fulfilled in the arbitration; I feel energetic; and I feel that through arbitration I am positively influencing others) indicate that activities related to arbitration generate feelings of satisfaction, a tendency to positively evaluate themselves and happiness. Thus, the greater the magnitude of your score, the higher the perception of sports achievement.

Pires, Santiago, Samulski, and Costa (2012) point out that in $\mathrm{ABQ}$, the three dimensions are related to each other. For example, there may be a link between depersonalization and emotional exhaustion, because from the manifestation of the feeling of exhaustion, the individual can exhibit impersonal behavior in his relationships in the organizational environment, which can contribute to personal dissatisfaction in the work environment. In this research, there was a high positive correlation between the negative dimensions (EFE and DES) and a high negative correlation between the two negative dimensions and the positive dimension (RE), meaning that the higher the RE score values, the lower the values presented at EFE and DES, and vice versa. Thus, BIR-AB evaluates the levels of burnout related to each dimension and identifies that high averages in emotional exhaustion and depersonalization and low averages in sports performance indicate high levels of burnout.

Thus, the BIR-AB proved to be adequate for the assessment of burnout for Brazilian basketball referees because it has better adjustment rates. The instrument's reliability showed acceptable values (between 0.6 and 0.8), according to Hair et al. (2009), in the three dimensions, corroborating the research by Brandão et al. (2014), whose BIR instrument also presented acceptable reliability between dimensions (between 0.6 and 0.8). Likewise, Pires et al. (2006) also showed satisfactory reliability $(0.8)$ in the validation of $\mathrm{ABQ}$ for Brazilian athletes. It is worth mentioning that reliability is not a fixed specificity of an instrument. According to Keszei, Novak, and Streiner (2010) and Roach (2006), reliability depends on a series of elements such as type of instrument, circumstances, context, and method of administration and characteristics of the sample, that is, the same instrument can be reliable for certain samples, while for others, no.

Finally, after carrying out the BIR-AB validation process, the importance of proposing an algorithm for measuring the scores for each of the dimensions (EFE, 


\section{Burnout Inventory for Referees (BIR) in Brazilian Basketball Referees}

DES, RE) and total burnout (BT) (Figure 4), through the weights of the factor-weighted scores calculated by AMOS with relative items, in order to numerically estimate the state of total burnout (BT) through a matrix of correlation weights (standardized values).

Unlike what was proposed in the original instrument by Weinberg and Richardson (1990), who obtained the total burnout score through the simple sum of all items, this simple arithmetic sum or average format does not apply to BIR-AB, since there was an elimination of items after the instrument validation process. Additionally, this format for obtaining the score assigns a weight of 1 to all items, which does not represent the actual value that each item has since each has a different factor load, representing it more reliably within the total construct of the burnout. It is also suggested that the 33 th percentile (P33) and the 66th percentile (P66) be used as cutoff points to classify the level of dimensions: physical and emotional exhaustion, depersonalization, sports performance, and total burnout, according to the parameters of Maslach and Jackson (1986).

Therefore, based on the previous discussions, it can be said that burnout is represented by a multidimensional syndrome (set of symptoms) that arises as a result of continuous exposure to stressful situations characteristic of the arbitration environment. In this context, it can be identified in Brazilian basketball referees through the presentation of components related to the dimensions of physical and emotional exhaustion, depersonalization, and sports performance.

Finally, it is known that the validation of an instrument must be a continuous process (Anastasi \& Urbina, 1997) and, therefore, a potential topic for future research. It is important to observe whether this configuration is maintained in samples of referees of different modalities sports or if it is specific to the population of this study, as well as whether it will be necessary to rewrite or add items that may also portray the manifestation of burnout in the population as a whole.

\section{PRATICAL APPLICATIONS}

This study on burnout in basketball referees can contribute with three valuable insights: first, to increase the knowledge about burnout syndrome in Brazilian basketball referees; second, to present a valid instrument to measure the syndrome in this population and, finally, based on this knowledge, to provide more effective psychological interventions and, consequently, a more accurate and balanced performance of the referees, avoiding the intention of abandoning the practice of refereeing.

\section{FUNDING}

This work was conducted during a scholarship supported by CAPES - Coordenação de Aperfeiçoamento de Pessoal de Nível Superior Brazilian Federal Agency for Support and Evaluation of Graduate Education within the Ministry of Education of Brazil. The results of the study are presented clearly, honestly, and without fabrication, falsification, or inappropriate data manipulation.

\section{REFERENCES}

1. Al-Haramlah, A. A. R. (2018). Psychological Stress, Burnout and its relationship with Decision Making among Table Tennis Referees: A case study on the Fourth Championship of Saudi Universities. Sportk: Revista Euroamericana de Ciencias del Deporte, 7(1), 103-110. https://doi.org/10.6018/321951

2. Almeida, F. R., Silva, C. B., Vendramini, C. M. M., Campos, C., \& Brandão, M. R. F. (2017). Propriedades psicométricas da versão brasileira da escala BRUMS para árbitros de basquetebol. Revista de Psicología del Deporte, 27(4), 37-44. https://doi.org/10.4321/s1578-84232012000300002

3. Anastasi, A., \& Urbina, S. (1997). Psychology testing. Upper Saddle River, NewJersey: PrenticeHall, Inc, 7a ed.

4. Arce, C., De Francisco, C., Andrade, E., Arce, I., \& Raedeke, T. (2010). Adaptación española del Ahtlete Burnout Questionnaire (ABQ) para la medida del burnout en futbolistas. Psicothema, 22(2), https://doi.org/10.1037/t37229-000 


\section{De Almeida et al.}

5. Balluerka, K., \& Gorostiaga, A. (2012). Elaboración de versiones reducidas de instrumentos de medida: una perspectiva práctica. Psychological Intervention, 2, 103-110. https://doi.org/10.5093/in2012v21n1a7

6. Beaton, D., Bombardier, C., Guillemin, F., \& Ferraz, M. B. (2002). Recommendations for the cross-cultural adaptation of health status measures. New York: American Academy of Orthopaedic Surgeons, 1-9.

7. Benevides-Pereira, A. M. (2001). MBI-Maslach Burnout Inventory e suas adaptações para o Brasil. Anais da XXXII Reunião Anual de Psicologia, 8485.

8. Brandão, M. R. F., Serpa, S., Rosado, A., \& Weinberg, R. (2014). Psychometric properties of the Burnout Inventory for Referees. Motriz: Revista de Educação Física, 20(4), 374-383. https://doi.org/10.1590/S1980-65742014000400003

9. Caccese, T. M., \& Mayerberg, C. K. (1984). Gender differences in perceived burnout of college coaches. Journal of sport psychology, 6(3), 279-288.https://doi.org/10.1123/jsp.6.3.279

10. Dale, J., \& Weinberg, R. S. (1989). The relationship between coaches' leadership style and burnout. The Sport Psychologist, 3(1), 1-13. https://doi.org/10.1123/tsp.3.1.1

11. De Francisco, C., Arce, C., Andrade, E., Arce, I., \& Raedeke, T. (2009). Propiedades psicométricas preliminares de la versión española del Athlete Burnout Questionnaire en una muestra de jóvenes futbolistas. Cuadernos de Psicología del Deporte, 9(2), 45. https://doi.org/10.1037/t37229-000

12. Fernández, C. A., Palacios, C. D. F., Fernández, E. M. A., Otero, M. J. F., Raedeke, T. D., \& de Murcia, A. (2012). Adaptación del ABQ para la evaluación del burnout en deportistas colombianos. Revista Iberoamericana de Psicología del Ejercicio y el Deporte, 7(2), 271286. https://doi.org/10.5093/rpadef2020a1

13. Fornell, C., \& Larcker, D. F. (1981). Evaluating structural equation models with unobservable variables and measurement error: Algebra and statistics. Journal of Marketing Research, 382388. https://doi.org/10.1177/002224378101800313

14. Garcés de Los Fayos, E. J. (1999). Burnout en deportistas: un estudio de la influencia de variables de personalidad, sociodemográficas y deportivas en el síndrome (Doctoral dissertation). Universidad de Murcia. https://doi.org/10.6018/cpd.367531
15. Guedes, D. P., \& Souza, R. O. (2016). Propriedades psicométricas do Athlete Burnout Questionnaire para uso em atletas jovens brasileiros. Journal of Physical Education, 27, e2708. https://doi.org/10.4025/jphyseduc.v27i1.2708

16. Hair, Jr., J. F., Anderson, R. E., Tatham, R. L., \& Black, W. B. (2009). Multivariate data analysis. Upper Saddle River, NJ: Prentice Hall.

17. Isoard-Gautheur, S., Oger, M., Guillet, E., \& Martin-Krumm, C. (2010). Validation of a French version of the Athlete Burnout Questionnaire (ABQ). European Journal of Psychological Assessment, 26(3), 203-211. https://doi.org/10.1027/1015-5759/a000027

18. Karademir, T. (2012). The factors that influence the burn-out condition of city football referees. Journal of Physical Education and Sport Management, 3(2), 27-34.

19. Keszei, A. P., Novak, M., \& Streiner, D. L. (2010). Introduction to health measurement scales. Journal of Psychosomatic Research, 68(4), 31923. https://doi.org/10.1016/j.jpsychores.2010.01.006

20. Kline, R. B. (2015). Principles and practice of structural equation modeling. Guilford publications.

21. Koh, J. Y., \& Hanrahan, S. J. (2017). Individualism, Collectivism, Burnout, and Sport Officials: A self-determination perspective. International Journal Sport Psychologist, 48, 375397.

22. Lee, R. T., \& Ashforth, B. E. (1990). On the meaning of Maslach's three dimensions of burnout. Journal of applied psychology, 75(6), 743. https://doi.org/10.1037/0021-9010.75.6.743

23. Lonsdale, C., Hodge, K., \& Rose, E. (2006). Pixels vs. Paper: Comparing online and traditional survey methods in sport psychology. Journal of Sport and Exercise Psychology, 28(1), 100-108. https://doi.org/10.1123/jsep.28.1.100

24. Lundkvist, E., Gustafsson, H., Davis, P. A., Holmström, S., Lemyre, N., \& Ivarsson, A. (2018). The temporal relations across burnout dimensions in athletes. Scandinavian Journal of Medicine \& Science in Sports, 28(3), 1215-1226. https://doi.org/10.1111/sms.13000

25. Marôco, J. (2014). Análise de equações estruturais: Fundamentos teóricos, software \& aplicações (2a ed). Lisboa: ReportNumber.

26. Marôco, J., Tecedeiro, M., Martins, P., \& Meireles, A. (2008). O Burnout como factor hierárquico de $2^{\mathrm{a}}$ ordem da Escala de Burnout de 


\section{Burnout Inventory for Referees (BIR) in Brazilian Basketball Referees}

Maslach. Análise Psicológica, 26(4), 639-649. https://doi.org/10.14417/ap.523

27. Marsh, H. W., Martin, A. J., \& Jackson, S. (2010). Introducing a Short Version of the Physical Self Description Questionnaire: New Strategies, ShortForm Evaluative Criteria, and Applications of Factor Analyses. Journal of Sport \& Exercise Psychology, 32, 438-482. https://doi.org/10.1123/jsep.32.4.438

28. Maslach, C., \& Jackson, S. E. (1981). The Measurement of Experienced Burnout. Journal of Occupational Behavior. 2(2), 99-113. https://doi.org/10.1002/job.4030020205

29. Maslach, C., \& Jackson, S. E. (1986). Maslach Burnout Inventory. Palo Alto, CA: Consulting Psychologists Press.

30. Palacios, C, F. (2015). Versión reducida del Athlete Burnout Questionnaire (ABQ): Propiedades psicométricas preliminares. Revista de Psicología del Deporte, 24(1), 177-183.

31. Pedrosa, I., \& García-Cueto, E. (2016). Síndrome de Burnout en Árbitros de Élite: la Liga de Fútbol Profesional Española (LFP) a Estudio. Revista Iberoamericana de Diagnóstico y Evaluación e Avaliação Psicológica, 42(2), 59-68. https://doi.org/10.21865/RIDEP42 59

32. Pereira, A. M. T. B. (2015). Elaboração e validação do ISB: inventário para avaliação da síndrome de burnout. Boletim de Psicologia, 65(142), 59-71.

33. Pires, D. A., Brandão, M. R. F., \& Silva, C. B. (2006). Validação do questionário de Burnout para atletas. Revista da Educação Física/UEM, 17(1), 27-36.

34. Pires, D. A., Santiago, M., Samulski, D., \& Costa, V. (2012). A Síndrome de Burnout no Esporte Brasileiro. Revista da Educação Física/UEM, 23, 131-139.

https://doi.org/10.4025/reveducfis.v23i1.14566

35. Raedeke, T. D. (1997). Is athlete Burnout more than Just stress? A sport commitment perspective. Journal of Sport and Exercise Psychology, 19(4), 396- 417. https://doi.org/10.1123/jsep.19.4.396

36. Raedeke, T. D., \& Smith, A. L. (2001). Development and preliminary validation of an athlete Burnout measure. Journal of Sport and Exercise Psychology, 23(4), 281-306. https://doi.org/10.1123/jsep.23.4.281

37. Raedeke, T. D., \& Smith, A. L. (2009). The Athlete Burnout Questionnaire Manual.
Morgantown, WV: Fitness Information Technology.

38. Roach, K. E. (2006). Measurement of health outcomes: reliability, validity and responsiveness. Journal of Prosthetics Orthotics, 18(1S), 8-12. https://doi.org/10.1097/00008526-200601001-00003

39. Ruviaro, M. D. F. S., \& Bardagi, M. P. (2010). Síndrome de burnout e satisfação no trabalho em profissionais da área de enfermagem do interior do RS. Barbarói, 33, 194-216.

40. Tamayo, M. R., \& Tróccoli, B. T. (2009). Construção e validação fatorial da Escala de Caracterização do Burnout (ECB). Estudos de Psicologia, 14(3), 213-221. https://doi.org/10.1590/S1413-294X2009000300005

41. Weinberg, R. S., \& Richardson, P. A. (1990). Psychology of officiating. Champaingn, IL: Leisure Press. 